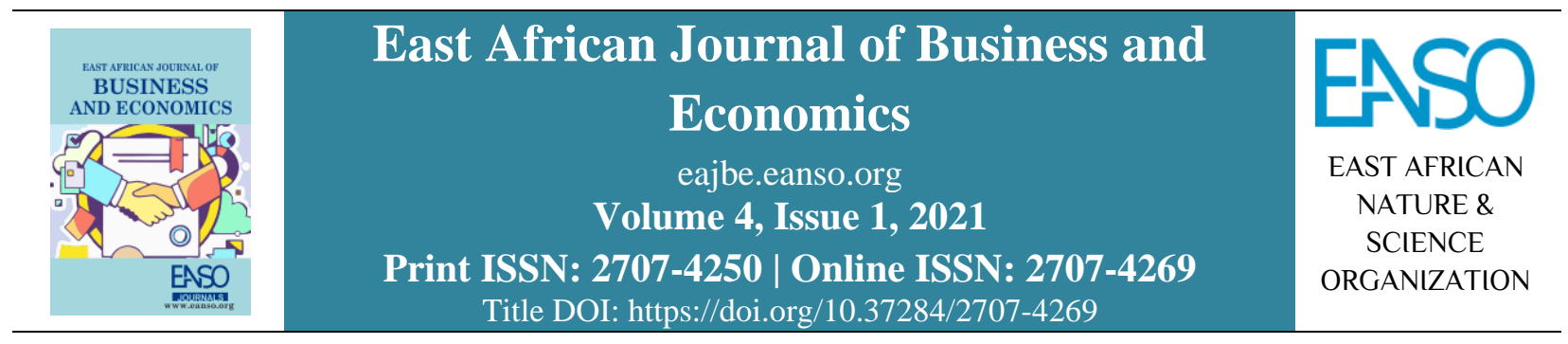

Original Article

\title{
An Assessment on the Influence of Capital Structure on Performance of the Listed Firms in Tanzania.
}

\author{
Martin Ayo ${ }^{1 *} \&$ Dr. Seif Muba \\ ${ }^{1}$ Mzumbe University Tanzania, P. O. Box 1 , Morogoro, Tanzania. \\ *Correspondence email: martin.ayo19@mustudent.ac.tz
}

Article DOI: https://doi.org/10.37284/eajbe.4.1.468

\section{Date Published: ABSTRACT}

10 November 2021 The research mostly assessed and established the influence of capital structure on the performance of firms listed under the Dar Es Salaam stock exchange

Keywords: (DSE). Specifically, the study aimed to assess the influence of total debt to equity ratio (TDE), total debt to assets ratio (TDA), total equity ratio (TEQ) on

Capital Structure,

Influence, the performance of listed firms in Tanzania. Also, the study aimed to determine the control effect of firm size (FS) on the relationship between firm Performance, performance and capital structure. The quantitative panel data approach was Firm Size, on ROA. Results indicated that only TEQ has a significant positive influence on the ROA while TDE and TDA have no significant influence on the ROA. Also, the fixed-effect model for ROCE was carried out to see the relationship between TDE and ROCE. Results showed that TDA and TEQ are insignificant to the ROCE, while TDE is significant to the ROCE. Findings also showed that the presence of the FS on the model of capital structure and ROA, results in TDA, and TEQ having a significant influence on ROA, while TDE becomes insignificant to ROA. Moreover, results indicated that the presence of the FS on the model of capital structure and ROCE results in the only TDE to have a significant influence on ROCE, while TDA and TEQ became insignificant to ROA. The study concluded that TDE has no significant influence on the ROA but TDE has a significant influence on ROCE. Also, the study concluded that TDA has no significant influence on both the ROA and ROCE while TEQ influences ROA positively, and has no significant influence on ROCE. Moreover, the study concluded that the presence of the FS on the model of capital structure and ROA, results in TDA, and TEQ having a significant influence on ROA, while TDE becomes insignificant to ROA. Furthermore, FS resulted in TDE having a significant influence on ROCE, while TDA and TEQ become insignificant to ROCE. The study recommends that companies very

1 | This work is licensed under a Creative Commons Attribution 4.0 International License. 
East African Journal of Business and Economics, Volume 4, Issue 1, 2021

Article DOI: https://doi.org/10.37284/eajbe.4.1.468

carefully must decide on a reasonable capital structure to maintain the performance of the company.

\section{APA CITATION}

Ayo, M., \& Muba, S. (2021). An Assessment on the Influence of Capital Structure on Performance of the Listed Firms in Tanzania. East African Journal of Business and Economics, 4(1), 1-13. https://doi.org/10.37284/eajbe.4.1.468

\section{CHICAGO CITATION}

Ayo, Martin \& Seif Muba. 2021. "An Assessment on the Influence of Capital Structure on Performance of the Listed Firms in Tanzania”. East African Journal of Business and Economics 4 (1), 1-13. https://doi.org/10.37284/eajbe.4.1.468.

\section{HARVARD CITATION}

Ayo, M., \& Muba, S. (2021) "An Assessment on the Influence of Capital Structure on Performance of the Listed Firms in Tanzania”, East African Journal of Business and Economics, 4(1), pp. 1-13. doi: 10.37284/eajbe.4.1.468.

\section{IEEE CITATION}

M. Ayo, \& S. Muba, "An Assessment on the Influence of Capital Structure on Performance of the Listed Firms in Tanzania”, EAJBE, vol. 4, no. 1, pp. 1-13, Nov. 2021.

\section{MLA CITATION}

Ayo, Martin \& Seif Muba. "An Assessment on the Influence of Capital Structure on Performance of the Listed Firms in Tanzania”. East African Journal of Business and Economics, Vol. 4, no. 1, Nov. 2021, pp. 1-13, doi:10.37284/eajbe.4.1.468

\section{INTRODUCTION}

Capital structure (CS) is the combination of debt and equity. CS shows the way firms finance their assets. It shows the combination of equity and debt. CS plays an important role in a firm's financial performance, as the optimal mix of the CS has the best interests on shareholder's wealth and the value of the company. Shareholders have an interest in maximizing their wealth (Le \& Phan, 2017). This then becomes critical for entrusted management to come up with a good mix of the CS by combining debt and equity effectively and efficiently to maximize the market value of the company and to meet the highly expected shareholders' interests (Chaganti \& Damanpour, 1991)

The decision is crucial as is a challenge for management especially the finance managers or directors as they must consider many factors affecting their business environment and also considering the forecasted future of the firm, financially. Many scholars have argued and, in their study, showed the significance of CS decisions on a firm's prosperity and maximizing shareholders' wealth (Chaganti \& Damapour, 1991).
The idea of CS and its effect on a firm's performance is a very critical topic and it is also backed up with many outdated theories, which, have argued that the CS cannot influence the value of the firm with the perfect market assumptions. But they later revised their theory in the defense of tax advantage towards debt that it can have an effect on the increase of the firm value (Chaganti \& Damanpour, 1991).

Some theories also relate that those firms which in the high-risk environments than those in a lower risk business environment should use less debt. Another theorem is that if a firm has many tangible assets, then they can employ a high debt rate than those with tangible assets because intangible is not used in collateral. CS theories attempt to explain whether a mixture of debt and equity is relevant and if so, it is, what might or should be the optimal CS (Nassar, 2016).

The lack of compromise among the theories and the reality in considering many factors while explaining the firm's performance in relation to CS has called for many empirical studies on the subject. It has called for many investigations in many years and in various parts of the world of which many conflicting results have been found with different contexts

$2 \mid$ This work is licensed under a Creative Commons Attribution 4.0 International License. 
(Basit \& Irwan, 2017). Basit and Irwan (2017) also indicate that there is no proper way of knowing the right debt fusion of debt to the equity that can maximize the firm's performance rather the management of the firm has a critical decision by considering the business environment and other current economic factors in setting the proper mix of their CS to attain good performance.

This is more challenging in developing countries, such as Tanzania. This is because the firms face many challenges such as undeveloped financial markets, non-performing loans, Government laws, and regulations changing constantly, lack of foreign currency, and other financing constraints. The finance managers or the management of such firms have to look at these variables affecting their CS and by doing so may come up with a proper mix to reach their performance objectives (Ajibola et al., 2018).

The agenda of CS has been a crucial topic or discussion of high concerns for many scholars in many years in the field of finance. Such importance has brought several discussions and arguments on the topic of which has set ways for many studies in this particular area up to now. Many studies have been conducted over the CS; however, the studies are either contradicted or inconclusive on the influence of CS on a firm's performance. Many methodologies and approaches have been previously tried to no single conclusion. This remains a need for further study to enlighten on the subject as this study sought a further investigation of CS on performance with reference to the listed firms on the DSE. The studies have been conducted at both international and local levels. Therefore, in the presence of these contradicting results of the studies, the current study intends to interrogate further and determine if CS can be influential on the performance of listed firms under the DSE while applying a panel data approach.

\section{LITERATURE REVIEW}

\section{Capital Structure}

A firm's CS is a combination of the firm's financial resources which encompasses the equity and debt that allows the firm to operate its business activities and assists for further financial investments to be attained. The sources of financing that a firm has and uses is very crucial because it has a great impact on its performance and if not attained at an optimum level that can generate a good return, then a firm can experience negative performance (Margaritis \& Psillaki, 2010). If the firm can attain a good and optimum CS is more likely to increase the market price of its shares and other securities that they own. The CS ratios such as DTE, DTA, and TEQ are used to measure the company's financial leverage. These ratios are crucial metrics applied in corporate finance. For instance, TDE is used to evaluate how the company finances its operations. To be more precise, the TDE always shows the shareholder's capacity to hold and cover all debts in the long run (Salim \& Yadav, 2012).

Also, according to Bhandari (1988), the TDA measures the financial leverage of a firm through the firm's total liabilities in comparison to how much of the firm's assets are financed through them. By doing so, the firms can have a clear picture of how much debt is used to finance the firm's assets. It is a good way of measuring the firm's solvency. Moreover, the TEQ was seen as a leveraged ratio that shows the portion of the firm's resources that are financed by contributions of the firm's equity and retained earnings. A high TEQ means the firm is highly financed through its funds of which to most investors is an attractive portfolio due to the minimum risk and well-managed firm.

\section{Review of Theories}

\section{Pecking Order Theory}

As indicated by Myers and Majluf (1984), the theory details assumptions that profitable firms will 
use less debt, in a sense that a firm will first finance itself through its internal funds of which is the lowest cost and lowest risk. If the firm fails to finance itself internally then there would be a second choice of issuing debt and lastly, if the latter and the former both fail, then the firm will have the last option of issuing new equity. The theory also suggests that the firm which has minimal investment opportunities and they have high cash flows will tend to obtain a low debt ratio and the opposite is the same for firms with many investments and a low cash flow will tend to have a high debt ratio. Moreover, this theory continues to clarify why profitable firms will have low debt ratios. This is not due to the fact that they consume little target debt ratios (Myers \& Majluf, 1984).

\section{The Signalling Theory}

This theory contends the assumption that information is not accessible equally to internal parties and external parties of the firm at the same time. The matter of information asymmetry arises; the firm's managers send signals to various investors for the purpose of balancing the information asymmetry of which can lead to good corporate financial decisions for the firm. In this case, the firm's managers have better information than investors for managers would opt to sell the firm's stocks when they are overvalued and sell bonds if the firm's stocks are undervalued. The theory states that the connection between performance and debt is a positive one. Since investors have general knowledge according to what is presented to them and that they view new stock sales as a negative signal, the choice of which signal to convey to the public investors remains for managers of the firm (Ross, 1977).

\section{Trade-off theory}

As elaborated by Frank and Goyal (2008) the tradeoff theory allows the firm to select how much of debt and how much of equity finance to use by trying to balance the costs and benefits such as the advantages of tax on adding more debt and also investment decisions. Thus, the theory means that firms should choose a trade-off between the distress costs of debt and the tax savings. Trade-off theory converts into an empirical proposition as it predicts a positive relationship between average debt ratios and profitability.

\section{Empirical Review}

A study done by Nassar (2016) conducted on 136 industrial companies listed on the Istanbul stock exchange, for a period of eight years ranging from 2005 to 2012 measured ROA, ROE, and earning per share to CS. The conclusion of this study showed a negative significant relationship between CS and the listed firms' performance. Rahman et al. (2019) researched the effect of CS on Bangladesh under the Dhaka stock exchange for 10 manufacturing firms for the period of four years from 2013 to 2017. The findings for the study were revealed that the DTR and TEQ had a significant positive effect but DTE has a significant negative impact on ROA.

Basit and Irwan (2018) studied the impact of CS on firms' performance of 50 chosen industrial product firms under the Bursa Malaysian main exchange from annual report data starting from 2011 to 2015. The results showed that the total equity ratio had a negative impact on firm performance, total equity ratio also had a negative impact on ROE, but the study found out that the total debt to equity ratio had a positive impact on both ROE and EPS. Nirajini (2013) conducted a study to determine the impact of CS on the financial performance of listed trading companies in Sri Lanka. For a period of four years from 2006 to 2010, the results revealed that CS had a significant relationship with firm performance. The debt to assets ratio had a positive relationship towards ROCE and ROA.

Javed et al. (2014) investigated the impact of CS on firm performance in Pakistan on 63 companies listed under the Karachi stock exchange for a period of five years beginning 2007 to 2011. The variables 
used under firm performance were ROA, ROE, and return on sales (ROS). The overall study and findings concluded that CS had a positive sign on firm performance so the firm's managers should focus more on obtaining that optimal level to reach their performance objective. A fixed-effects model was used as pooled regression model by the researchers under study.

In Nigeria, Nelson and Peter (2019) studied to determine the effect of CS on ROE for the banking sector on the focus of microfinance banks for a period of nine years (2009-2018). The results revealed a negative and insignificant relationship between DTE and ROE, but a positive and significant connection between TDR and ROE.

Akingunola et al. (2017) examined the impact of CS decisions on financial performance on 22 nonfinancial firms listed under the Nigeria stock exchange for a period of four years from 2011 to 2015. The result indicates that performance measured by ROE is discreetly positively

\section{Figure 1: Conceptual framework}

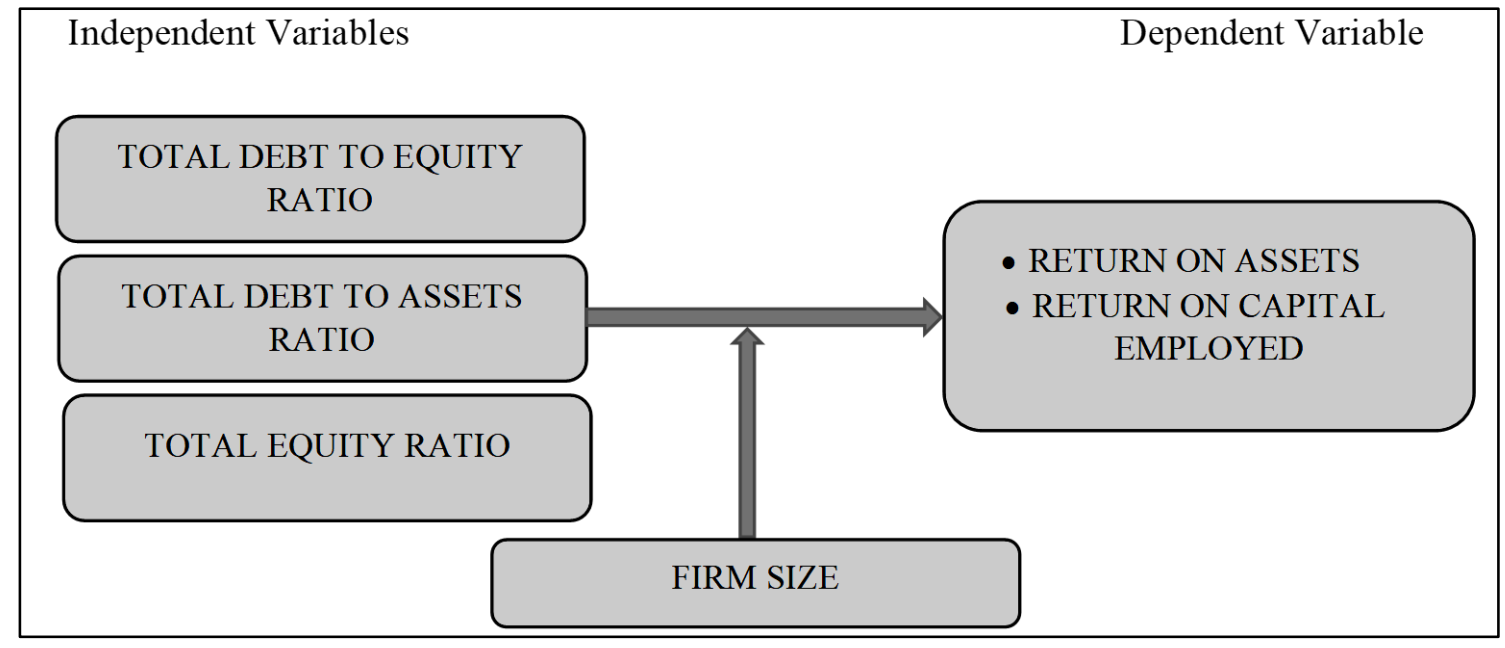

\section{RESEARCH METHODS}

The study applied a quantitative longitudinal research design based on a deductive approach where the secondary information of ROA, ROCE, TDE, TDA, TEQ, and FS from the 10 firms listed influenced by leverage, while ROA with leverage showed a negative relationship. Long-term debt to the total asset was found to have a significant positive effect on ROE while total debt to total equity had a significant negative effect on ROE.

Therefore, empirical evidence on the impact of CS on company performance provides mixed results. For example, some researches have exposed that there is evidence that there is a significant positive correlation between CS and company performance; Others have described the negative impact of CS on company performance.

\section{Conceptual framework}

The framework depicts the relationship between CS and firm performance of listed firms on the DSE. CS is presented by TDE, TDA, and TEQ. Firm performance is presented by ROCE and ROA. CS is the explanatory variable, whereas firms' performance is the dependent variable, and FS is a control variable. The relationship between CS and firm performance is indicated in Figure 1. 
$\operatorname{ROA}(\mathrm{Y})=\mathrm{a}+\beta_{1} X_{1}+\beta_{2} X_{2}+\beta_{3} X_{3}+\beta_{4} X_{4}+\varepsilon$

Where; ROCE = Return on Capital Employed, ROA $=$ Return on Assets, $\mathrm{a}=$ intercept, $\beta_{n}=$ coefficient to be estimated, TDE = Total Debt to Equity Ratio, TDA = Total Debt to Asset Ratio, TEQ $=$ Total Equity Ratio, FS = Firm size, and $\varepsilon=$ error term.

\section{FINDINGS OF THE STUDY}

\section{Descriptive Analysis}

The study applied means, median, standard deviations, maximum and minimum value, of the variables under study from 10 listed companies in DSE to present descriptive statistics in Table 1.

\section{Table 1: Descriptive Statistics}

\begin{tabular}{llllll}
\hline Variables & Mean & Median & Min & Max & Std. dev \\
\hline TDE & 3.6797 & 1.3083 & -5.5748 & 96.4106 & 10.0016 \\
TDA & 0.5691 & 0.5667 & 0.1889 & 1.2186 & 0.2631 \\
TEQ & 0.4220 & 0.4333 & -0.9186 & 1.1123 & 0.2992 \\
FS & 12.2932 & 12.3830 & 8.8352 & 15.6959 & 1.9547 \\
ROA & 0.1119 & 0.0669 & -0.2628 & 0.4837 & 0.1420 \\
ROCE & 0.2639 & 0.2793 & -0.4966 & 0.8978 & 0.2562 \\
Observation & 100 & 100 & 100 & 100 & 100 \\
\hline
\end{tabular}

Results in Table 1 show that in a total of 100 observations, the TDE has a mean of 3.6797 indicating that on average the firms had 3.7 shillings of debt for every 1 shilling in equity. Moreover, the result indicates that the minimum and maximum values of the TDE from 2010 to 2019 are -5.5748 and 96.4106 respectively. A negative minimum value of TDE shows that in some of the listed companies interest rates on its debts are larger than the ROA. Companies that experience a negative TDE may be seen as risky to lenders, analysts, and investors for the reason that this debt is a sign of financial instability.

Also, the TDA has a mean of 0.5691 indicating that debt constitutes approximately $57 \%$ in relation to total assets owned by the firms. Moreover, the result indicates that the minimum and maximum values of the TDA from 2010 to 2019 are -0.1889 and 1.2186 respectively. The minimum value of the TDA of less than one $(<1)$ means that the companies contain more assets than liabilities, and if necessary, they can repay the liabilities by trading assets.

Findings in Table 1 also show that the mean for TEQ is 0.4220 indicating that about $42 \%$ of the firm's equity is relative compared to total assets owned by firms. Also, TEQ has a minimum value of -0.9186 and a maximum value of 1.1123 in the respective years. The minimum value of negative of TEQ shows that the company at a given time is at risk because at this stage the company experience more liabilities than assets.

Also, findings indicate that the FS experienced the minimum and maximum values of 8.8352 and 15.6959 respectively. The firm size was measured by total assets; thus, the maximum value of FS implies that some companies at a given time experience the growth of their businesses.

Furthermore, the findings in Table 1 also show that the mean of the ROA is 0.1119 which indicates that the ROA was $11.19 \%$ or to say for each one shilling invested in assets the firms generated an average of 11.2 cents of net income. These findings reveal that at least every of the listed companies in DSE gets profits as the mean value and standard deviation of ROA are nearly close. Also, ROA has a minimum value of -0.2628 and a maximum value of 0.4837 in the respective years among the listed companies. 
Additionally, findings show that the mean of ROCE is 0.2639 which indicates that the ROCE was $26.39 \%$ showing that for each shilling invested the firms generated an average of 26.4 cents in profits. Also, findings indicate that the ROCE experienced the minimum and maximum values of -0.4966 and 0.8978 respectively. The negative minimum value of ROCE implies that companies have highly negative working capital beyond the size of their net fixed assets. This also implies that some companies are making poor use of their capital resources.

\subsection{A unit root test}

The test of Harris-Tzavalis was used to check if the data contains a unit root problem. Therefore, TDE, TDA, TEQ, FS, ROA, and ROCE were tested and the results are presented in Table 2. Findings in Table 2 reveal that all variables passed the condition of stationarity at a 5\% significance level, therefore, it is concluded that all variables are stationary at level [I(0)].

Table 2: Harris-Tzavalis Test for Unit Root

\begin{tabular}{lllllll}
\hline Variable & TDE & TDA & TEQ & FS & ROA & ROSE \\
\cline { 2 - 7 } & rho & & & & & \\
\hline Test statistic & -0.0936 & 0.3333 & 0.3980 & 0.1528 & 0.4300 & 0.4303 \\
$\mathrm{Z}$ & -9.4169 & -4.5200 & -3.7777 & 0.2929 & -3.4101 & -3.4068 \\
P-value & 0.0000 & 0.0000 & 0.0001 & 0.0152 & 0.0003 & 0.0003 \\
Decision & Reject $\mathrm{H}_{0}$ & Reject $\mathrm{H}_{0}$ & Reject $\mathrm{H}_{0}$ & Reject $\mathrm{H}_{0}$ & Reject $\mathrm{H}_{0}$ & Reject $\mathrm{H}_{0}$ \\
Conclusion & Stationary & Stationary & Stationary & Stationary & Stationary & Stationary \\
\hline
\end{tabular}

\section{Fixed Effect Results for ROA}

The Hausman test preferred the fixed effect model to be used to the estimate values of the variables whereby TDE, TDA, TEQ are taken as independent variables, and FS is taken as a control variable, while ROA is taken as a dependent variable. The analysis includes two types of results i.e., Results when there is no control variable and results when there is a control variable. The test was done and the results are shown in Table 3 for fixed effect results for ROA without the control variable (FS), and for fixed effect results for ROA with a control variable (FS).

Table 3: Fixed Effect Results for ROA

\begin{tabular}{|c|c|c|c|c|c|c|}
\hline \multicolumn{7}{|c|}{ Fixed Effect Results for ROA without a Control Variable (FS) } \\
\hline ROA & Coef. & Std. Err. & $\mathbf{t}$ & $\mathbf{p}>|\mathbf{t}|$ & {$[95 \%$ conf. } & rval] \\
\hline DTE & -0.0010715 & 0.0007596 & -1.41 & 0.162 & -0.0025812 & 0.0004382 \\
\hline DTA & -0.1123017 & 0.0755147 & .1 .49 & 0.141 & -0.2623953 & 0.0377919 \\
\hline TEQ & 0.1141417 & 0.0527154 & 2.17 & 0.033 & 0.009364 & 0.2189193 \\
\hline _Cons & 0.1315814 & 0.0608392 & 2.16 & 0.033 & 0.0106569 & 0.2525058 \\
\hline R-sq: within & 0.2413 & & & & & \\
\hline between & 0.7105 & & & & & \\
\hline Overall & 0.5475 & & & & & \\
\hline $\mathrm{F}(3,87)$ & 9.22 & & & & & \\
\hline Prob $>F$ & 0.0000 & & & & & \\
\hline
\end{tabular}


East African Journal of Business and Economics, Volume 4, Issue 1, 2021

Article DOI: https://doi.org/10.37284/eajbe.4.1.468

\begin{tabular}{|c|c|c|c|c|c|c|}
\hline \multicolumn{7}{|c|}{ Fixed Effect Results for ROA with a Control Variable (FS) } \\
\hline ROA & Coef. & Std. Err. & $\mathbf{t}$ & $\mathbf{p}>|\mathbf{t}|$ & \multicolumn{2}{|c|}{ [95\% conf. Interval } \\
\hline DTE & -0.0008833 & 0.0007406 & -1.19 & 0.236 & -0.0023555 & 0.000589 \\
\hline DTA & -0.1499638 & 0.747479 & -2.01 & 0.048 & -0.2985577 & -0.00137 \\
\hline TEQ & 0.1034349 & 0.0513149 & 2.02 & 0.047 & 0.0014243 & 0.2054455 \\
\hline FS & -0.0507003 & 0.0199805 & -2.54 & 0.013 & 0.904202 & -0.0109804 \\
\hline _Cons & 0.780107 & 0.2623043 & 2.97 & 0.004 & 0.2586633 & 1.301551 \\
\hline R-sq: within & 0.2941 & & & & & \\
\hline between & 0.2020 & & & & & \\
\hline Overall & 0.2036 & & & & & \\
\hline $\mathrm{F}(4,86)$ & 8.96 & & & & & \\
\hline Prob $>F$ & 0.0000 & & & & & \\
\hline
\end{tabular}

The first part of Table 3 indicates results of fixed effect results for ROA without a control variable (FS). Results indicate that the overall p-value (Prob $>\mathrm{F}=0.0000$ ) is less than the significant level at $5 \%$, statistically, this result shows that the model is good to forecast the influence of CS on the performance of firms. Also, results show that in the absence of the control variable FS, only TEQ is significant to the ROA at a p-value (0.033) while the rest of the variables are not significant. This shows that the absence of FS for every one-unit increase in TEQ increases ROA by 0.1141417 . Also, results show that the overall coefficient of determination is 0.5475 (54.75\%), this implies that in the absence of FS, $54.75 \%$ of the variation in ROA is explained by independent variables while $45.25 \%$ of the variation in ROA is described by other factors not studied in this study.

The second part of Table 3 indicates results of fixed effect results for ROA with a control variable (FS). Results indicate that the overall p-value (Prob $>\mathrm{F}=$ 0.0000 ) is less than the significant level at $5 \%$, statistically, this result shows that the model is good to forecast the influence of CS on the performance of firms. Also, results show that the overall coefficient of determination is 0.2036 (20.36\%), this implies that $20.36 \%$ of the variation in ROA is explained by TDE, TDA, TEQ, and FS while $79.64 \%$ of the variation in ROA is described by other aspects not considered in this research.
Moreover, results in Table 3 indicate that TDE is not statistically significant at $5 \%$ while TDE, TEQ, and FS are statistically significant at p-values of 0.048 , 0.047 , and 0.013 respectively. Therefore, results imply that TDE and TEQ influence the performance of the firms while the presence of the control variable (FS) shows the significant contribution (effect) on the relationship between CS and performance of firms (ROA) listed in DSE. Findings also reveal that TDA has a negative influence on the ROA whereby for every change of one unit in TDA results change in ROA by 0.1499638 , thus, for every one-unit increase in TDA results decrease in ROA by 0.1499638 . Also, findings reveal that TEQ has a positive influence on ROA whereby for every change of one unit in TEQ results change in ROA by 0.1034349 , thus, for every one-unit increase in TEQ results increase in ROA by 0.1034349 . Moreover, results show that every one-unit increase in FS decreases the significant contribution on the link between CS and ROA by 0.0507003 . Moreover, the introduction of FS into the model reduces the coefficient of determination to $0.2036(20.36 \%)$.

\section{Fixed Effect Results for ROCE}

The Hausman test preferred the fixed effect model to be used to the estimate values of the variables whereby TDE, TDA, TEQ are considered as independent variables, and FS is taken as a control variable, while ROCE is taken as a dependent 
East African Journal of Business and Economics, Volume 4, Issue 1, 2021

Article DOI: https://doi.org/10.37284/eajbe.4.1.468

variable. The analysis includes two types of results i.e., Results when there is no control variable and results when there is a control variable. The test was carried out and the results are indicated in Table 4 for fixed effect results for ROCE without the control variable (FS), and for fixed effect results for ROCE with a control variable (FS).

Table 4: Fixed Effect Results for ROCE

\begin{tabular}{|c|c|c|c|c|c|c|}
\hline \multicolumn{7}{|c|}{ Fixed Effect Results for ROCE without a Control Variable (FS) } \\
\hline ROCE & Coef. & Std. Err. & $\mathbf{t}$ & $\mathbf{p}>|\mathbf{t}|$ & \multicolumn{2}{|c|}{ [95\% conf. Interval] } \\
\hline DTE & -0.0047356 & 0.0018395 & -2.59 & 0.011 & -0.0083739 & -0.0010973 \\
\hline DTA & -0.2000895 & 0.1819835 & -1.10 & 0.275 & -0.5618015 & 0.1616224 \\
\hline TEQ & -0.003025 & 0.1270394 & -0.02 & 0.981 & -0.2555295 & 0.2494795 \\
\hline _Cons & 0.396458 & 0.1466169 & -2.70 & 0.008 & 0.105041 & 0.687875 \\
\hline R-sq: within & 0.1122 & & & & & \\
\hline between & 0.4015 & & & & & \\
\hline Overall & 0.2489 & & & & & \\
\hline $\mathrm{F}(3,87)$ & 3.67 & & & & & \\
\hline Prob $>\mathrm{F}$ & 0.0153 & & & & & \\
\hline \multicolumn{7}{|c|}{ Fixed Effect Results for ROCE with a Control Variable (FS) } \\
\hline ROCE & Coef. & Std. Err. & $\mathbf{t}$ & $\mathbf{p}>|\mathbf{t}|$ & \multicolumn{2}{|c|}{ [95\% conf. Interval } \\
\hline DTE & -0.0042393 & 0.0017716 & -2.39 & 0.019 & -0.0077612 & -0.0007175 \\
\hline DTA & -0.2993593 & 0.1788072 & -1.67 & 0.098 & -0.6548163 & 0.0560977 \\
\hline TEQ & -0.0312458 & 0.1227523 & -0.25 & 0.800 & -0.2752692 & 0.2127776 \\
\hline FS & -0.1336359 & 0.0477961 & -2.80 & 0.006 & -0.2286514 & -0.0386203 \\
\hline _Cons & 2.105842 & 0.6274681 & 3.36 & 0.001 & 0.8584763 & 3.353207 \\
\hline R-sq: within & 0.1862 & & & & & \\
\hline between & 0.0000 & & & & & \\
\hline Overall & 0.0048 & & & & & \\
\hline$F(4,86)$ & 4.92 & & & & & \\
\hline Prob $>F$ & 0.0013 & & & & & \\
\hline
\end{tabular}

The first part of Table 4 indicates results of fixed effect results for ROCE without a control variable (FS). Results in Table 4 indicate that the overall pvalue (Prob $>\mathrm{F}=0.0000$ ) is less than the significant level at $5 \%$, statistically, this result shows that the model is good to forecast the influence of CS on the performance of firms. Also, results show that in the absence of the control variable FS, only TDE is significant to the ROCE at a p-value (0.011) while the rest of the variables are not significant. This shows that in the absence of FS, every one-unit increase in TDE decreases ROCE by 0.0047356 . Also, results show that the overall coefficient of determination is 0.2489 (24.89\%), this implies that in the absence of FS, $24.89 \%$ of the variation in ROCE is explained by independent variables while $75.11 \%$ of the variation in ROCE is described by other aspects not considered in this research.

The second part of Table 4 indicates results of fixed effect results for ROCE with a control variable (FS). Results in Table 4 indicate that the overall p-value (Prob $>\mathrm{F}=0.0013$ ) is less than the significant level at $5 \%$, statistically, this result shows that the model is good to forecast the influence of CS on the performance of firms. Also, results show that the overall coefficient of determination is 0.0048 
$(0.48 \%)$, this implies that $0.48 \%$ of the variation in ROCE is explained by TDE, TDA, TEQ, and FS while $99.52 \%$ of the variation in ROCE is explained by other factors not studied in this study.

Moreover, results in Table 4 indicate that TDA and TEQ are not statistically significant at $5 \%$ while TDE and FS are statistically significant at $p$-values of 0.019 , and 0.006 respectively. Therefore, results imply that TDE influences the performance of the firms while the presence of the control variable (FS) shows the significant contribution on the relationship between CS (TDE) and performance of firms (ROCE) listed in DSE. Findings also reveal that TDE has a negative influence on the ROCE whereby for every change of one unit in TDE results change in ROCE by -0.0042393 , thus, for every one-unit increase in TDE results decrease in ROCE by 0.0042393 . Moreover, results show that every one-unit increase in FS decreases the significant contribution on the relationship between TDE and ROCE by 0.1336359 . Moreover, the introduction of FS into the model reduces the coefficient of determination to $0.0048(0.48 \%)$.

\section{DISCUSSION}

Results indicate that TDE has no significant influence on the ROA. These results are in line with Fatoki (2018) who revealed that there is no significant relationship between TDE and ROA. The findings are also supported by Toraman (2013), and Myers and Majluf (1984) who found that no significant influence of TDE on ROA. Also, the results of this research are different from those of (Namalathasan, 2010); Basit and Irwan, 2018; Rehman, 2013), who showed that the DTE is positively related to ROA. The DTE is important to the company as it compares the company's total liabilities with its shareholders' equity and can be used to assess how much leverage the company uses. A higher debt-to-equity ratio often portrays that the company or stock has a higher risk to shareholders. Also, results show that TDE is significant to the ROCE. These findings are different from Fatoki (2018) who found that TDE has no significant influence on ROCE. These findings are also supported by Wasiuzzaman and Arumugam (2013) who studied CS and its profitability. The findings revealed that TDE has a significant influence on ROCE. Hence, the choice of CS is a significant decision that companies must consider.

Also, results indicate that TDA has no significant influence on the ROA. These results are supported by Fatoki (2018) who revealed that there is no significant relationship between TDE and ROA. However, these findings are different from the findings by Abor (2008) and Kirmi (2017) from the petroleum companies. The findings of their studies showed a significant positive relationship between the ratio of short-term debt to total assets and profitability. The ratio of total debt to total assets allows investors to get a rough idea of the financial strength and CS of a company and how it finances operations. This can also be affirmed by Frank and Goyal (2008) in the trade-off theory which states that firms should choose a trade-off between the distress costs of debt and the tax savings. Firms with safe, tangible assets and plenty of taxable income to shield should have high target debt ratios. On the other side, results show that TDA is insignificant to the ROCE. Fatoki (2018) supported this result as with the exception of ROCE, the effects of all explanatory variables were statistically significant at all levels of the CS measurement.

Moreover, results indicate that TEQ has a significant influence on the ROA. The results also indicate that TEQ influences ROA positively. These findings are supported by Namalathasan (2010), Rouf and Abdur (2015), and Basit and Irwan (2018) who indicated that TEQ influences ROA. This result can also be supported by Bhandari (1988) who claimed that a high equity ratio means the firm is highly financed through its funds of which to most investors is an attractive portfolio due to the minimum risk and well-managed firm. A higher value-to-equity ratio usually indicates that the 
company has effectively met its asset needs with the least amount of debt. On the other hand, results show that TEQ is insignificant to the ROCE.

Findings show that the FS has a significant effect on the relationship between CS and ROA. The results also indicate that the presence of the FS on the model of CS and ROA, results in TDA, and TEQ to have a significant influence on ROA, while TDE becomes insignificant to ROA. The negative effect of FS on the relationship between CS and ROA implies that FS modifies the relationship of the company inversely i.e. As the FS increases, the connection between CS and ROA decreases, and as FS decreases the relationship between CS and ROA increases. These findings also are claimed by Kurshev and Strebulaev (2006) who found that there is a significant positive correlation between firm size and CS for the performance of the firm. The availability of funds and company profit as indicated by Hamyat et al. (2017) is largely affected by the size of the company. A small business found it difficult to raise debt funds.

Moreover, findings show that the firm size has a significant effect on the relationship between CS and ROCE. The results also indicate that the presence of the FS on the model of CS and ROCE results in the only TDE to have a significant influence on ROCE, while TDA and TEQ variables become insignificant to ROA. Also, the negative effect of FS on the relationship between CS and ROCE implies that FS modifies the relationship of the company inversely i.e. As the FS increases, the relationship between CS and ROCE decreases, and as FS decreases the relationship between CS and ROCE increases. Kanwal et al. (2017) by using 213 listed firms from Karachi Stock Exchange got similar results while Ogbeide and Akanji (2018) by using 27 listed firms from Nigeria came up with different findings.

\section{CONCLUSION}

The study concluded that TDE has no significant influence on the ROA but TDE has a significant influence on ROCE. Also, the study concluded that TDA has no significant influence on both the ROA and ROCE while TEQ influences ROA positively, and has no significant influence on ROCE. Moreover, the study concluded that the presence of the FS on the model of capital structure and ROA, results in TDA, and TEQ having a significant influence on ROA, while TDE becomes insignificant to ROA. Furthermore, FS resulted in TDE having a significant influence on ROCE, while TDA and TEQ become insignificant to ROCE.

\section{Recommendation}

First, it is recommended that companies very carefully must take debt financing as an option in their capital portfolio to achieve the best limit because the DTE has a significant positive influence on the performance of the company.

Second, since TDE has a significant influence on ROCE, it should be noted that the ratio of debt to equity in different companies is different. This is because different types of companies require different levels of capital and debt to operate and expand. Thus, the study suggests that companies should use optimal levels of debt to maintain the performance of their companies.

Third, if a company wants to improve its profitability, it also needs to expand its scale in terms of customer base, net assets, sales, and market share. Expanding companies will not only improve their profitability but also help them gain a competitive advantage over other companies, as larger institutions are expected to be more efficient than their smaller counterparts and have better resources to weather the economic downturn. 


\section{REFERENCES}

Ajibola et al, A. (2018). Capital structure and financial performance of listed manufacturing firms in Nigeria. Journal of Research in International Business and Management, 5(1), 81-89.

Abor, J. (2008). Determinants of the capital structure of Ghanaian firms. AERC.

Akingunola, R. O., Olawale, L. S., \& Olaniyan, J. D. (2018). Capital structure decision and firm performance: Evidence from non-financial firms in Nigeria. Acta Universitatis Danubius. Economica, 13(6).

Basit, A., \& Irwan, N. (2017). The Impact of Capital Structure on Firms Performance: Evidence from Malaysian Industrial Sector -A Case-Based Approach. International Journal of Accounting \& Business Management, 131-149.

Basit, A., \& Irwan, N. (2018). The Impact of Capital Structure On Firms Performance: Evidence From Malaysian Industrial Sector -A CaseBased Approach. International Journal of Accounting \& Business Management.

Bhandari, L. C. (1988). Debt/equity ratio and expected common stock returns: Empirical evidence. The journal of finance, 43(2), 507528.

Chaganti, R., \& Damanpour, F. (1991). Institutional ownership, capital structure, and firm performance. Strategic management journal, 12(7), 479-491.

Fatoki, O. I. (2018). Effect of Financial Performance on Capital Structure of NonFinancial Firms in the Nigerian Stock Exchange. JKUAT-COHRED.

Frank, M. Z., \& Goyal, V. K. (2008). Trade-off and pecking order theories of debt. Handbook of empirical corporate finance, 135-202.
Hamyat, H., Sarita, B., \& Hasbudin, S. (2017). The Effect of Firm Size and Diversification on Capital Structure and Firm Value (Study in Manufacturing Sector in Indonesia Stock Exchange). The International Journal of Engineering and Science (IJES), 1813-2319.

Javed, T., Younas, W., \& Imran, M. (2014). Impact of capital structure on firm performance: Evidence from Pakistani firms. International Journal of Academic Research in Economics and Management Sciences, 3(5), 28.

Kanwal, M., Shahzad, S. J. H., ur Rehman, M., \& Zakaria, M. (2017). Impact of capital structure on performance of non-financial listed companies in Pakistan. Pakistan Business Review, 19(2), 339-353.

Kirmi, P. N. (2017). Relationship between capital structure and profitability, evidence from listed energy and petroleum companies listed in Nairobi Securities Exchange. Journal of Investment and Management, 6(5), 97-102.

Kurshev, A., \& Strebulaev, I. (2006). Firm Size and Capital Structure. Quarterly Journal of Finance, 05. https://doi.org/10.2139/ssrn.676106

Le, T. P. V., \& Phan, T. B. N. (2017). Capital structure and firm performance: Empirical evidence from a small transition country. Research in International Business and Finance, 42, 710-726.

Margaritis, D., \& Psillaki, M. (2010). Capital structure, equity ownership, and firm performance. Journal of Banking \& Finance, 34(3), 621-632.

Miller, M., \& Modigliani, F. (1958). The Cost of capital. Corporate Finance and the Theory of Investment. American Economic Review, 48, 261-297.

Myers, S. C., \& Majluf, N. S. (1984). Corporate financing and investment decisions when firms 
have information that investors do not have. Journal of financial economics, 13(2), 187-221.

Namalathasan, B. (2010). Capital Structure and its Impact on Profit Ability: A Study of Listed Manufacturing Companies in SRI Lanka. Journal for Economic Theory and Practice and Social Issues, 56(1350-2019-2397), 83-92.

Nassar, S. (2016). The impact of capital structure on Financial Performance of the firms: Evidence From Borsa Istanbul. Journal of Business and financial affairs.

Nelson, J., \& Peter, E. A. (2019). An empirical analysis of effect of capital structure on firm performance: Evidence from microfinance banks in Nigeria. European Journal of Accounting, Auditing and Finance Research, 7(9), 30-44.

Nirajini, A. (2013). Impact of Capital Structure on Financial Performance of the Listed Trading Companies in Sri Lanka. International Journal of Scientific and Research Publications.

Ogbeide, S., \& Akanji, B. (2018). Stock market development and economic growth of Brazil, Russia, India, China, and South African (BRICS) Nations: An empirical research.

Rahman et al, M. A. (2019). The impact of capital structure on the profitability of publicly traded manufacturing firms in Bangladesh. Applied Economics and Finance, 6(2), 1-5.

Ross, S. A. (1977). The determination of financial structure: the incentive-signaling approach. The bell journal of economics, 23-40.

Rouf, D., \& Abdur, M. (2015). Capital structure and firm performance of listed non-financial companies in Bangladesh. The International Journal of Applied Economics and Finance, 9(1), 25-32.
Salim, M., \& Yadav, R. (2012). Capital structure and firm performance: Evidence from Malaysian listed companies. Procedia-Social and Behavioral Sciences, 65, 156-166.

Wasiuzzaman, S., \& Arumugam, V. C. (2013). Determinants of working capital investment: a study of Malaysian public listed firms. Australasian Accounting, Business and Finance Journal, 7(2), 63-83. 